\title{
COST OF CAPITAL AND RISK IN MANAGEMENT AND QUALITY SCIENCE
}

\author{
Aneta MICHALAK \\ Silesian University of Technology, Faculty of Organization and Management; Poland; aneta.michalak@polsl.pl, \\ ORCID: 0000-0002-0935-6674
}

Purpose: The purpose of the article is to review two important issues within management and quality sciences, namely capital management and risk management.

Design/methodology/approach: Due to the cognitive nature of the article, the aim of the work will be achieved using the method of analyzing the literature on the subject. Literature studies include Polish and foreign publications.

Findings: The conducted literature analysis has shown that sources dealing with capital management issues and the cost of capital treat the problem of risk very casually. Similarly, in publications referring to the issue of risk, it rarely refers to capital and its cost. This paper indicates the need for a comprehensive approach to these two issues, indicating the close relationship between them that occurs in the field of management and quality sciences.

Research limitations/implications: The research presented in the article is theoretical and may contribute to further empirical research.

Practical implications: The practical implications of the conducted research are associated with the possibility of their application for the needs of management decisions in enterprises.

Originality/value: A review of the literature on the subject shows that the issues of capital management and risk management are often treated separately and undertaken as independent research areas. This article indicates the need for a comprehensive approach to capital management and risk management and their consideration. The author proves that management decisions regarding raising capital result in a specific cost of capital. This in turn largely depends on the level of risk associated with investing in the enterprise.

Keywords: cost of capital, risk, management and quality science.

Category of the paper: General review.

\section{Introduction}

Management is a complex process that constitutes one of the most important factors in economic growth. The theory of management reaches back to the 18th century. The precursors of management science are thought to be A. Smith, R. Owen and Ch. Babbage. The dynamic 
development of management was a result of the industrial revolution. At the end of the 19th century, management became a scientific discipline, and its beginning is assumed to be the date of publication of the first papers related to the trend of scientific work organization. Among the founders of management theory related to this trend, one should mention F.W. Taylor, H.L. Gantt, F.B. Gilbreth (the representatives of American scientific centers), H. Fayol and H. Le Chatelier (the French scholars) and K. Adamiecki (Polish development center of management Sciences).

In the Polish legal system, management sciences were initially classified as economic sciences. Over time, the interdisciplinarity of this scientific discipline and the practical approach to management have begun to be emphasized. The consideration of, in particular, the psychology and other social sciences and humanities used in management has resulted in a dichotomous approach to management sciences. The discipline is included in two areas of science: economic sciences and humanities (Resolution of the Central Commission for Degrees and Titles of 23 June 2003; Act of 14 March 2003). From 2018, management science has been transformed into a management and quality science discipline which is in the field of social science (Regulation of the Minister of Science and Higher Education of 20 September 2018). Placing among social sciences clearly indicates that management and quality sciences are linked to the activities of people, and more specifically of people and institutions created by them (Drucker, 1980). The management process takes place through people's reactions and actions, which lead to changes in specific states of affairs. For example, we deal with "enterprise management", "capital management" or "risk management". The management process always consists in activity of people who operate in these areas and who want to achieve specific objectives in these areas.

Capital management and risk management belong to those management areas where decisions contributing to the achievement of common goals are made. These two areas of management are interdependent. If management decisions concerning capital are considered in isolation from other factors, they are assumed to be intended to minimize the cost of capital. Similarly, the purpose of risk management, with consideration of other fixed factors, is its minimization. The combination of these two management areas means that, if the cost of capital is considered to be the overriding premise of management decisions, the management objective will be to achieve a minimum cost of capital at an acceptable level of risk. In turn, if risk is to be the overriding premise of the decisions, the objective of management in these areas will be to minimize risk at an acceptable level of cost of capital. As one can see, capital and risk management cannot be limited to minimizing cost of capital and minimizing risk. The problem is far more complex. Both those parameters - cost of capital and risk - are strongly correlated and they cannot be analyzed in isolation. In the management process, one needs to choose which of the parameters is more relevant from the perspective of optimizing its value, and which can be left on an acceptable level. For example, by reducing risk, we engage capital by hedging against risk, agreeing to a certain cost, and by minimizing the cost of capital, we accept a certain 
level of risk. Both of these management areas need to be defined and clarified. The purpose of this article is to indicate the need for a comprehensive approach to capital management and risk management. The article is cognitive in nature and the basic research method is the analysis of literature on the subject.

\section{Institutional and functional contexts of management}

Management has been defined in literature many times and in several different ways. But its essence always boils down to the implementation of basic functions, which should be fulfilled in every enterprise, on every level and in all its areas, i.e. in the area of production, finances, research and development, marketing, and others. These functions include planning, organization, leadership, motivation and control. One can find institutional and functional approaches to management in literature. Management in the institutional sense refers to a group of people who are entrusted with decision making and giving orders to other employees of an organization. In the functional sense, management is a set of tasks which have to be executed in order to run a system. The functional approach refers to all the activities necessary to carry out the organization's tasks, which must be executed in order to achieve its objectives. In the functional approach, management is seen as administration of the use of resources. Management, therefore, occurs in all areas of the enterprise's activity, in the form of management of supplies, human resources, projects, finances, physical resources, as well as capital and risk. Each use of resources (human, physical or information resources) in particular areas is understood as a set of actions aimed at achieving the organization's objectives in an efficient and effective manner.

\section{Capital management issues}

The management of capital in an enterprise's activity is multithreaded and complex (Michalak, 2011, p. 267-276). It is defined as raising capital, managing it rationally, efficiently and effectively, as well as using it to multiply the value of an enterprise in conditions of acceptable risk (Borowiecki, 1993). Capital management is concerned with investment and financial decisions of the enterprise, especially long-term decisions related to the long-term development strategy of the enterprise (Brealey, Myers, 1991; Bernstein, 2007; Kapil, 2011). An important element of capital management process is the methodology of cost of capital calculation. It has not only an important scientific significance, but also application significance, influencing rational decisions in enterprises and their efficient functioning, as well 
as contributing to the achievement of their goals. The use of information on the cost of capital in the decision-making process in an enterprise is, therefore, closely related to the need of application of appropriate methods of its estimation (in order to manage something, one has to measure it). This is an important feature of issues within the field of management sciences (Sudoł, 2016, p. 4-11) and it locates decisions concerning capital and determining the cost of capital in the area of capital management.

With regard to capital management issues, the core management functions can be specified as follows:

- planning the demand for capital and planning the capital structure, together with corresponding cost (budgeting),

- organizing capital by raising it on a financial market and within an enterprise (providing financing),

- control, monitoring of capital deployment.

Determining the cost of capital is one of the long-term financial decisions of an enterprise, which belong to the area of enterprise capital management (Jajuga, 1993, p. 9).

\section{Cost of capital as a management instrument}

The literature defines the cost of capital as rate of return on capital invested that is expected by investors (both owners and creditors) with a given level of risk (Alexander, 1995). The significance of risk in defining the cost of capital should be highlighted. Undertakings with the same risk profile have the same cost of capital and the rate of return expected by investors should be at least equal to the highest total return that investors would expect if they had invested in an alternative undertaking with the same risk profile (Duliniec, 2012, p. 1-18; Byrka-Kita, 2008, p. 26). According to this approach, the cost of capital results from the relation between the risk and rate of return. The riskier the enterprise's activities, the higher the rate of return it has to generate and the higher the cost of capital (Garber, Hammitt, 1998; JonekKowalska, 2019; Jonek-Kowalska, and Nawrocki, 2019). The cost of capital is therefore determined by the expectations of creditors and owners as to the rate of return on the assets held by the enterprise (Haugen, Senbet, 1978, p. 26).

The cost of capital is a research problem that arises in various fields and disciplines and in economic practice. It is also present in the management and quality sciences. Management and quality sciences are, most of all, applied sciences. In their areas, theoretical generalizations are formulated for enterprises based on practical actions. Research conducted in this area is of an application nature and aims to formulate practical directives (Lichtarski, 2007, p. 59-60). In the field of management and quality sciences, not cognitive results, but methodological results are sought. Cognitive results consist in developing a model of a certain reality, which 
allows to predict the future, i.e. to explain the laws governing this reality (nature, economy, society). The essence of a scientific cognitive result is discovering a law that governs the reality, which is of a universal nature and can serve for prediction (laws can be formulated in the form of research hypotheses). Methodological results consist in developing a method for solving a particular scientific problem (the scientific method makes it possible to construct the future, is universal in nature and serves as a predictive tool, and therefore meets the conditions of a scientific result). Management and cost of capital take place in already existing reality, which is governed by certain laws. The methodology of capital management, together with methods of calculating the cost of capital, focus on the methodological aspect of science (Grabowski, Pratt, 2008). The complexity and broad scope of this issue should be highlighted. It raises a very important methodological question, which needs to be answered at the beginning of the considerations carried out in this area. This question is a kind of dilemma, that has already been raised in the literature on the subject. It concerns the extent, to which an enterprise has an influence on the cost of capital, whether it is a parameter or an instrument in the hands of managers. A clear position on this issue is taken by Prof. B. Włoszczowski, who asks a question: “Cost of capital: a parameter of calculation or management instrument?" (Włoszczowski, 2005, p. 45). He submits to methodological considerations the problem of whether the cost of capital is an independent parameter in calculations made in various circumstances (estimation of value, calculation of profitability of investments etc.) or whether it is one of the instruments of enterprise management. A parameter is defined in the area of economics and organization of an enterprise as an economic value on which enterprises cannot exert a noticeable influence. Thus, parameter is seen as an independent (external) variable, to which decisions and actions are adjusted. The change of parameters usually requires launching adaptation processes in enterprises. Examples of parameters include competitive market equilibrium prices, exchange rates, stock prices, interest rates of the National Bank of Poland, tax rates etc. Instruments, on the other hand, are seen as the opposite of parameters. They can be defined as a deliberately shaped economic value, which is used to achieve the intended effects in the process of enterprise management. Instruments include corporate prices, terms and conditions for entering into agreements and lending, cost levels, dividends etc. Some researchers regard the cost of capital as an objective parameter deriving directly from the capital market (Michalak, 2013). However, if we assume that the cost of capital is more than just a rate of return for investors on the capital market, being a remuneration for incurred non-diversified systematic risk (market, general economy risk), then it acquires the characteristics of an instrument used in the process of managing the enterprise. If we look at the cost of capital through the prism of systematic risk (on which an enterprise has no influence) and specific risk (internal, individual, which can be shaped by an enterprise) then the cost of capital depends, to some extent, on decisions made by the owners and management (Groth, 1997). Management decisions will decide on its final shape, through the influence of factors dependent on the enterprise (generating specific risks). Thus, one can assume that when we see the cost of capital through the prism of systematic risk, 
i.e. calculate it using traditional methods of capital asset valuation, e.g. CAPM (Capital Asset Pricing Model), we are dealing with a parameter (McGoun, Zielonka, 2000). By contrast, the instrumental approach to the cost of capital arises when, from an objective calculation parameter external to the company, the cost of capital is transformed into an instrument for managing the enterprise, shaped not only by external factors (systematic risk), but also by internal factors dependent on the enterprise (specific risk). The instrumentalization of the cost of capital consists in including specific risk in the methods of its calculation. This demonstrates the close relationship between the cost of capital and risk and justifies the need for a comprehensive approach to capital management and risk management.

\section{Issues of risk in capital management}

Several different factors influence the cost of capital in an enterprise. The most important one is considered to be the business risk of the enterprise or the risk inherent in the assets of the enterprise in the conditions where debt is not used. Business risk can mean uncertainty about the amount of future cash flows, sales volumes, delivery liquidity and many other factors. Risk management literature relates risk to many aspects of economic activity (Slade, 2020; Katanaeva et al, 2020; Gonzi et al, 2019). One of them is the cost of capital. As this risk increases, so does the rate of return required by investors and, at the same time, the cost of capital. Risk as an economic phenomenon is determined by a number of different factors (Jonek-Kowalska, Turek, 2011) which shape its level and, at the same time, influence the cost of capital. The source of the specific risk can be the company management manner, liquidity, financial leverage and operational leverage, availability of raw materials and other factors (Bijańska, Wodarski, 2014). Since the sources of the specific risk originate in an enterprise or industry, it is generally believed that, under conditions of capital investment in listed shares, this risk can be reduced or even eliminated by the investor by constructing a diversified portfolio of securities. However, this rule cannot apply to entities whose shares are not listed and in conditions where the capital investor does not diversify its investment portfolio and becomes, for example, a strategic investor in a given enterprise. In such conditions, the specific risk has a particular significance of the investor (Rydzewska, 2018).

In turn, the systematic risk refers to general economic conditions, it is a result of external forces, which are beyond the control of an entity subject to the risk. It is related to macroeconomic factors, such as economic situation, monetary and fiscal policy, social situation, legal system etc. This risk applies to all entities operating in a given market and is not diversified. 
In view of the specific and systematic risks involved, the cost of capital should include a specific risk premium and a systematic risk premium. A lot of attention is paid to this issue in the area of capital management, considering risk as one of the most important determinants of the cost of capital.

Due to the significant role of risk - not only in the field of capital management, but also in other enterprise management areas - it became a separate area of management (Bizon-Górecka, 2005).

The main objective of risk management in an enterprise is:

- identification of risk sources,

- estimation of risk,

- developing appropriate strategies for action.

Thus, depending on the context, a two-pronged approach to risk is possible. It can be one of the factors that determine management decisions in other areas of enterprise management, e.g. in the area of capital management. It can also be the subject of management in the area of enterprise risk management. The wide scope of this issue makes it difficult to define boarders of these two contexts of risk. At the same time, there is a problem with the perception of risk management in management and quality sciences. There is still no clear definition of this issue as a sub-discipline of management and quality sciences. Risk management is often perceived as an element of strategic management, value management, crisis management or business continuity management (Staniec, 2012, p. 259). In practice, risk management is often confused with risk hedging. Risk management should be oriented at the positive and negative side of risk and its aim should be to exploit the positive side of risk and to secure and prepare for the materialization of negative risk. Unfortunately, this perception of risk management is not yet widespread enough. Two trends in the approach to risk management can be found in the literature on the subject (Staniec, 2012):

1) risk management as a synonym of insurance management, deals only with negative effects of risk, which are most often subject to insurance (narrow risk perception and limited risk management),

2) risk management through shaping risk policy in order to lower the cost of capital and treating risk as an element of the organization's decision-making process.

\section{Conclusions}

Management sciences are concerned with the creation, functioning, transformation, development and cooperation of business organizations. Capital is an inherent element of each of the above areas. It is necessary to finance the assets constituting the first equipment of a newly established enterprise, it determines its functioning by shaping its production capacity 
(production, trade, service capacity) during its operation, enables financing of development projects and even liquidation of the enterprise (especially in sectors where the liquidation process may be more capital-intensive than the establishment process). Without capital with an appropriate structure and cost, it is impossible to shape the value of an enterprise. Having the role of capital in the process of sustainable development of an enterprise in mind, it is necessary to identify capital with the element determining the economic existence of the enterprise. It is, therefore, a subject of research in the field of management sciences. Methods of calculating the cost of capital also have their place in management sciences. Management is a science "which results in socially useful knowledge in the form of established regularities of economic or social life and theories which explain a particular field of reality, provide projects to be applied and help rationalize this reality" (Sudol, 2007, p. 8). Methods of calculating the cost of capital are those "projects to be applied", which take into account the effects of risk management in the enterprise, present certain regularities and help rationalize decisions taken in the sphere of capital management.

The issue of the cost of capital and risk may be considered in management sciences in several ways, perceived according to various criteria (Sudoł, 2012, p. 37), among others:

- according to type of organization - on the level of enterprise management,

- according to management function - on the level of planning and organizing financial capital,

- according to processes - on the level of basic process, consisting in financing the core operational activity of an enterprise,

- according to areas of activity - on the level of capital management,

- according to resources - on the level of financial resources,

- according to management levels - on the level of strategic management (refers to longterm capital) and operational management (short-term capital).

\section{Acknowledgements}

This paper was financed from the resources of the Silesian University of Technology, project no. BK-235/ROZ-1/2020 (13/010/BK_20/0042). 


\section{References}

1. Alexander, I. (1995). Cost of Capital. The Application of Financial Models to State Aid. Oxford: OXERA.

2. Bernstein, P.L. (2007). Capital Ideas Evolving. Hoboken, New Jersey: J. Wiley\&Sons, Inc.

3. Bijańska, J., Wodarski, K. (2014). Ryzyko w decyzjach inwestycyjnych przedsiębiorstw. Zeszyty Naukowe Politechniki Śląskiej, seria: Organizacja i Zarzadzanie.

4. Bizon-Górecka, J. (2005). Ryzyko. Zarządzanie ryzykiem w przedsiębiorstwie. Bydgoszcz: Towarzystwo Naukowe Organizacji i Kierownictwa.

5. Borowiecki, R. (1993). Zarządzanie kapitałem trwałym w przedsiębiorstwie. Kraków: Wyd. Akademii Ekonomicznej.

6. Brealey, R.A., Myers, S.C. (1991). Principles of Corporate Finance. New York: McGrawHill.

7. Byrka-Kita, K. (2008). Metody szacowania kosztu kapitału własnego. Teoria a praktyka. Rozprawy i Studia Uniwersytetu Szczecińskiego, 689. Szczecin: Wyd. Naukowe Uniwersytetu Szczecińskiego.

8. Drucker, P.F. (1980). The Frontiers of Management. New York.

9. Duliniec, A. (2012). Koszt kapitału w teorii i praktyce przedsiębiorstw. Gospodarka Narodowa, 3(247).

10. Garber, S., Hammitt, J.K. (1998). Risk premiums for environmental liabilities: superfund and the cost of capital. Journal of Environment and Economic Management, 36.

11. Gonzi, R.D., Grima, S., Kizilkaya, M., Spiteri, J. (2019). The Dali Model in RiskManagement Practice: The Case of Financial Services Firms. Journal of Risk and Financial Management, 12, 4.

12. Grabowski, R.J., Pratt, S.P. (2008). Cost of capital: applications and examples. New Jersey: John Wiley and Sons.

13. Groth, J.C., Anderson, R.C. (1997). The cost of capital: perspectives for managers. Management Decisions, 6.

14. Haugen, R., Senbet, L. (1978). The Insignificance of Bankruptcy Costs to the Theory of Optimal Capital Structure. Journal of Finance, May.

15. Jajuga, K. (1993). Zarządzanie kapitałem. Wrocław: Wyd. Akademii Ekonomicznej.

16. Jonek-Kowalska, I. (2019). Efficiency of enterprise risk management (ERM) systems Comparative analysis in the fuel sector and energy sector on the basis of Central-European companies listed on the Warsaw Stock Exchange. Resources Policy, 62, pp. 605-615.

17. Jonek-Kowalska, I., Nawrocki, T. (2019). Holistic fuzzy evaluation of operational risk in Polish mining enterprises in a long-term and sectoral research perspective. Resources Policy, 63. 
18. Jonek-Kowalska, I., Turek, M. (eds.) (2011). Zarzadzanie ryzykiem operacyjnym w przedsiębiorstwie górniczym. Warszawa: $\mathrm{PWN}$.

19. Kapil, S. (2011). Financial Management. India: Dorling Kinderlsey; New Delhi, licensees of Pearson Education in South Asia.

20. Katanaeva, M.A., Grozovsky, G.I., Lartseva, T. (2020). Risk-oriented thinking in the quality management system of an organization. Revista Inclusiones, 7, 1.

21. Lichtarski, J. (2007). O endogenicznych barierach rozwoju nauk o zarządzaniu. In: Dynamika zarządzania organizacjami. Paradygmaty - Metody - Zastosowania. Katowice: Wyd. Akademii Ekonomicznej.

22. McGoun, E.G., Zielonka, P. (2000). O metodologicznym podłżu modelu CAPM. Bank Kredyt, 4.

23. Michalak, A. (2013). Problems of capital categorization in economic sciences and economic practice. In: S. Majtan (ed.), Aktuálne Problémy Podnikovej Sféry 2013. Bratislawa: Ekonomická Univerzita v Bratislave, Vyd. EKONOM.

24. Michalak, A. (2001). Identyfikacja źródeł finansowania inwestycji rozwojowych przedsiębiorstw górniczych na tle innych branż kapitałochłonnych. Zarządzanie finansami. Inwestycje, wycena przedsiębiorstw, zarządzanie wartością. Zeszyty Naukowe Uniwersytetu Szczecińskiego, 639, seria Finanse, Rynki Finansowe i Ubezpieczenia, 37. Szczecin.

25. Rozporządzenie Ministra Nauki i Szkolnictwa Wyższego z dnia 20 września 2018 r. w sprawie dziedzin nauki i dyscyplin naukowych oraz dyscyplin artystycznych. Warszawa, dated 25 September 2018, item 1818.

26. Rydzewska, A. (2018). Zarządzanie wartością przedsiębiorstw niefinansowych w obliczu procesów finansjalizacji. Zarzadzanie i Finanse, 16, 4/1.

27. Slade, P. (2020). Business risk management programs under review. Canadian Journal of Agricultural Economics-Revue Canadienne d Agroeconomie, Jan.

28. Staniec, I. (2012). Zarządzanie ryzykiem w naukach o zarządzaniu. In: A. Czech (ed.), Nauki o zarządzaniu - u początków i współcześnie. Zeszyty Naukowe Uniwersytetu Ekonomicznego w Katowicach. Katowice.

29. Sudoł, S. (2016). Zarządzanie jako dyscyplina naukowa. Przegląd Organizacji, 4.

30. Uchwała Centralnej Komisji do Spraw Stopni i Tytułów z dnia 23 czerwca 2003 r. w sprawie określenia dziedzin nauki i dziedzin sztuki oraz dyscyplin naukowych i artystycznych, M.P. 2003 no. 40, item 586.

31. Ustawa z 14 marca 2003 o stopniach naukowych i tytule naukowym oraz o stopniach i tytule w zakresie sztuki, JoL of 2003, no. 65, item 595.

32. Włoszczowski, B. (2005). Metodologiczne dylematy rachunku kosztu kapitału i ryzyka. Zeszyty Naukowe Politechniki Łódzkiej, Organizacja i Zarządzanie, 958. Łódź. 